\title{
Anxiety Levels of Children During Electrophysiological Study
}

\section{Elektrofizyolojik Çalışma Sırasında Çocuklarda Anksiyete Düzeyleri}

\author{
Özgün Araştırma \\ Research Article \\ Tülay Demircan $\odot$, Gonca Özyurt $\odot$, Baris Guven $\odot$, Kayı Eliaçık $\odot$, Nazmi Narin $\odot$ \\ Cem Karadeniz $\odot$
}

\section{ABSTRACT}

Amaç: Elektrofizyolojik çalışma (EFÇ) taşikardi tanı ve tedavisinde kullanılmaktadır. Bu çalışmanın amacı EFÇ öncesi çocuklardaki anksiyete seviyesini tespit etmektir.

Yöntem: Bu kesitsel çalışmaya Mart ve Eylül 2019 tarihleri arasında EFÇ için hastaneye yatırılan 45 olgu alındı. 8-18 yaş arasıçocuklardan oluşan hasta grubu yaş ve cinsiyet uyumlu kontrollerle karşılaştıııldı ( $n=46)$. Çocuklarda anksiyete bozukluklarını tarama ölçeği (Screen for Child Anxiety Related Emotional Disorders (SCARED) kullanılarak çocuklardaki anksiyete şiddeti değerlendirildi.

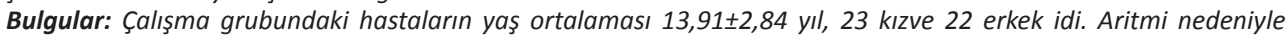
işleme alınan olguların tanıları \%44,4 atriyoventriküler reentran tasikardi, \%31 AV nodal reentran taşikardi, \%22,2 ventriküler taşikardi, \%8,8 sinüs taşikardisi ve \%4,4 atriyal flatter idi. Elektrofizyolojik çalışma işlemi için hastaneye yatırılan çocuklarda anksiyete düzeyleri kontrol grubuna göre daha yüksek olarak bulundu $(p<0,001)$.

Received/Geliş: 25.07.2020

Accepted/Kabul: 24.08.2020 Sonuç: Bildiğimiz kadarıyla, çalışmamız Türkiye'de taşikardi nedeniyle EFÇ yapılan çocuklarda anksiyete düzeyini ölçen ilk çalışmadır. Elektrofizyolojik çalıșmai şlemi çocuklarda anksiyeteyi artırmaktadır. Anksiyeteyi azaltan yöntemlerin çalışıldığı ileri çalışmalara ihtiyaç vardır.

Published Online: 29.04.2021

Tülay Demircan Tepecik Eğitim ve Araștırma Hastanesi, Pediyatrik Kardiyoloji Bölümü, Izmir - Türkiye

tulay.sirin@hotmail.com ORCID: 0000-0002-2529-2906

B. Güven 0000-0002-4520-5574 Tepecik Eğitim ve Araștırma Hastanesi, Pediyatrik Kardiyoloji Bölümü, izmir, Türkiye

G. Özyurt 0000-0002-0508-0594 Izmir Katip Çelebi Üniversitesi, Çocuk ve Adolesan Ruh Sağlığı ve Hastalıkları Anabilim Dalı, Izmir, Türkiye

K. Eliaçık 0000-0001-9529-9719 Tepecik Eğitim ve Araştırma Hastanesi, Çocuk Sağlığı ve Hastalıkları Kliniği, Izmir, Türkiye

N. Narin 0000-0003-2713-364X C. Karadeniz 0000-0003-0529-2391 Izmir Katip Çelebi Üniversitesi, Pediyatrik Kardiyoloji Bölümü, Izmir, Türkiye

Cite as: Demircan T, Özyurt G, Guven B, Eliaçık K, Narin $N$, Karadeniz C. Anxiety levels of children Narin N, Karadeniz C. Anxiety levels of children during electrophysiological study. Tepecik Ë ve Araşt. Hast. Dergisi. 2021;31(1):97-102.

\section{Anahtar kelimeler: Anksiyete, elektrofizyolojik çalışma, aritmi}

\section{öz}

Objective: Electrophysiological study (EPS) has been widely used in the diagnosis and treatment of tachycardia. The objective of this study was to determine the anxiety levels in children before EPS procedure.

Method: Patients ( $n=45)$ who were hospitalized for EPS between March and September of 2019 were included $n$ this cross-sectional study, The patient group consisting of children aged 8-18 years old was compared with ageand sex-matched controls $(n=46)$. We evaluated the severity of anxiety at the time of assessment using the Screen for Child Anxiety Related Emotional Disorders (SCARED) scale. The forms were filled out by both children and their parents.

Results: The mean age of the patients in the study group consisting of 23 girls and 22 boys was $13.91 \pm 2.84$ years. Diagnoses of cases treated due to arrhythmia were as follows: atrioventricular reentrant tachycardia (44.4\%), atrioventricular nodal reentrant tachycardia (31\%), ventricular tachycardia (11.2\%), sinus tachycardia (8.8\%), and atrial flutter (4.4\%). Anxiety levels were higher in children who were hospitalized for EPS procedure compared to the control group $(p<0.001)$.

Conclusion: As far as we know, our study is the first in Turkey to measure the level of anxiety in children undergoing cardiac EPS due to tachycardia. Electrophysiological study procedure increases anxiety in children. Further studies in which methods to reduce anxiety are needed are studied.

Keywords: Anxiety, electrophysiological study, arrhythmia

(C) Telif hakkı T.C. Sağık Bakanlığı İzmir Tepecik Eğit. ve Arașt. Hastanesi. Logos Tip Yayıncılık tarafindan yayınlanmaktadır.

Bu dergide yayınlanan bütün makaleler Creative Commons Atf-GayriTicari 4.0 Uluslararası Lisansı ile lisanslanmıştır.

(c) Copyright Association of Publication of the T.C. Ministry of Health İzmir Tepecik Education and Research Hospital.

This journal published by Logos Medical Publishing.

Licenced by Creative Commons Attribution-NonCommercial 4.0 International (CC BY) 


\section{INTRODUCTION}

Palpitations and arrhythmia are frequent reasons for admission to pediatric outpatient clinics and emergency services ${ }^{(1)}$. Supraventricular tachycardia is the most common tachyarrhythmia in children ${ }^{(2,3)}$.It accounts for more than $90 \%$ of childhood arrhythmias ${ }^{(2)}$.While $80 \%$ of infants are affected by atrioventricular reentrant tachycardia (AVRT), atrioventricular nodal reentrant tachycardia (AVNRT) is more common in the later years ${ }^{(2,4)}$.The most common form of AVRT is Wolf-Parkinson-White syndrome (WPW). Wolff-Parkinson-White syndrome is characterized by short PR intervals, delta waves and wide QRS complexes detected on the surface electrocardiograms ${ }^{(5,6)}$. Electrophysiological study has been increasingly used for the diagnosis and treatment of arrhythmias in children (e.g.radiofrequency ablation and cryoablation) in recent years. After the electrophysiological study, the patient's palpitations can be eradicated completely ${ }^{(4)}$.In adult patients, the procedure can be performed using sedoanalgesia. The use of general anesthesia to allow pediatric patients to undergo a comfortable electrophysiology study is becoming the standard of care ${ }^{(7)}$.Optimal anesthetic agent for pediatric electrophysiological study, should have minimal effect on cardiac conduction system. These anesthetic agents should adequately suppress the sympathetic responses to induction and stimulation to allow predictable progression of procedure ${ }^{(7)}$. Preoperative anxiety is important in these patients. Preoperative anxiety may delay the onset of activity of stress hormones and induction of anesthesia and also prevent postoperative recovery. ${ }^{(8)}$.

Previous studies have indicated that emotional and behavioral problems are more common in children with chronic diseases ${ }^{(9,10)}$. These problems are more likely to exhibit internalizing symptoms, such as anxiety, depression, and social functioning difficulties, rather than externalizing symptoms such as conduct disorder or physical aggression ${ }^{(10)}$. These internalizing problems may worsen with physical problems and physical problems may also increase the severity of chronic symptoms ${ }^{(9)}$. Heart rhythm disorders are classified as chronic diseases, and like other chronic diseases they can cause anxiety and stress, leading to symptoms such as an increase in palpitations, which may cause higher levels of anxiety $^{(11)}$. Here, we wanted to detect the level of anxiety in children who were hospitalized for electrophysiological study.

\section{MATERIAL and METHOD}

This study included 45 children aged between 8-18 years who were hospitalized in Pediatric Cardiology Clinic of Tepecik Training and Research Hospital for electrophysiological study between September and March of 2019. All patients underwent pre-ablation screening tests including 12-lead electrocardiography, a transthoracic echocardiography and pre-anesthetic evaluation. Patients with any psychiatric disorder and chronic disease (diabetes mellitus, hypertension, rheumatic and immunological diseases, epilepsy, genetic diseases and and also non-native Turkish speakers were excluded. Parents of children undergoing electrophysiological study (none of whom had any previous history of psychiatric illnesses) were included in the study.The control group included age and-sex matched children without any structural heart disease who had been referred to the pediatric cardiology outpatient clinic for cardiac evaluation with echocardiographic examination for innocent murmurs. The study protocol was approved by the local ethicsl committee (2019/14-18).

When a child hospitalized for the electrophysiological study, a pediatric cardiologist explained the study and obtained the parent and child's consent. The survey consisted of two parts. The first part contained questions about socio-demographic status of the participants, and the second part consisted of responses to the Screen for Child Anxiety Related Emotional Disorders (SCARED) scale questions (12). 
The questionnaires were given to both child and parents approximately 24 hours before child's catheterization.The individuals who were responsible for the care of the child e.g. mother, father or another person filled out the forms. Sociodemographic data inquired were related to child's age, gender, education level of parents, marital status (single, married, domestic partnership, or divorced), number of children in family ranked by age, age of the mother, perceived socioeconomic status, parents' profession, and history of presence of medical and psychiatric disease in a family member.

\section{The Screen for Child Anxiety Related Emotional Disorders (SCARED):}

The SCARED is a 41-item scale that aims to indicate how children have felt over the previous three months.We used the scale for parents and children to determine the anxiety levels in children. The form comprises 41 questions that evaluate the child's anxiety. Response given to each question is being scored as 0,1 , or 2 points, depending on the severity of the symptom. The total score is calculated, and a cut-off point of 25 is suggested to indicate the presence of an anxiety disorder. The Screen for Child Anxiety Related Emotional Disorders form was developed in 1997, and a Turkish validity and reliability study was carried out by Çakmakçı et al. in $2003^{(13)}$.

After the parents were informed, electrophysiological study was applied to the intubated patient under general anesthesia. Antiarrhythmic medications were discontinued for at least five half-lives in all patients before the electrophysiological study was conducted. Three-dimensional (3D) right atrial geometry was reconstituted without fluoroscopy. A minimum dose of anesthetic agent was used for general anesthesia, because high dose anesthetic agent may make it difficult to detect the foci of arrhythmia.

\section{Statistical analyses}

Statistical analysis was performed using SPPS 24.0 (SPSS, Inc., Chicago, IL, USA) program. Homogenous distribution of data was evaluated with KolmogorovSmirnov test. Parametres with homogenous distribution in diseased and control children were compared using Student T test. Chi-square test was used for the comparison of group scores. Differences in terms of the mothers' age, family income status, history of medical and psychiatric diseases between the patient and control groups were checked by Pearson chisquare test. Any $p$ value detected under 0.05 was considered to be significant.

\section{RESULTS}

Patients with rhythm disorder $(n=45)$ and control subjects $(n=46)$ were included in study. The mean age of the patients was $13.91 \pm 2.84$ years and there were no differences between the study and the control groups in terms of age and gender (Table 1). Among 45 patients who underwent electrophysio-

Table 1. Age, gender, cardiac diagnoses, parent-child closeness, marital status, and number of siblings: EPS group and Control group.

\begin{tabular}{|c|c|c|c|}
\hline & $\begin{array}{l}\text { EPS group } \\
\text { (mean } \pm S D S)\end{array}$ & $\begin{array}{c}\text { Control group } \\
\text { (mean } \pm S D S)\end{array}$ & p value \\
\hline Age (year) & $13.91 \pm 2.84$ & $13.23 \pm 2.96$ & 0.273 \\
\hline \multicolumn{4}{|l|}{ Gender } \\
\hline Girl (n,\%) & 23 & 23 & \multirow[t]{2}{*}{0.916} \\
\hline Boy (n, \%) & 22 & 23 & \\
\hline \multicolumn{4}{|l|}{ Diagnoses (n,\%) } \\
\hline AVRT (WPW) & $20(44.4)$ & - & - \\
\hline AVNRT & $14(31.0)$ & - & - \\
\hline VT & $5(11.10)$ & - & - \\
\hline SinusTachycardia & $4(8.80)$ & - & - \\
\hline AT & $2(4.40)$ & - & - \\
\hline \multicolumn{4}{|l|}{ Treatment } \\
\hline RFA & $14(31.11)$ & - & - \\
\hline Cryoablation & $25(56.81)$ & - & - \\
\hline Diagnostic EPS & $6(13.33)$ & - & - \\
\hline \multicolumn{4}{|l|}{ Parents } \\
\hline Mother & $35(79.50)$ & $42(91.30)$ & \multirow[t]{3}{*}{0.231} \\
\hline Father & $8(18.18)$ & $4(8.60)$ & \\
\hline Other & $1(2.20)$ & 0 & \\
\hline \multicolumn{4}{|l|}{ Parent marital status } \\
\hline Married & $39(88.60)$ & $39(88.60)$ & \multirow[t]{2}{*}{1} \\
\hline Divorced & $5(11.40)$ & $5(11.40)$ & \\
\hline \multicolumn{4}{|l|}{ Number of siblings } \\
\hline Non & $6(13.60)$ & $4(9.00)$ & \multirow[t]{4}{*}{0.376} \\
\hline 1 & $23(52.27)$ & $28(63.63)$ & \\
\hline 2 & $6(13.63)$ & $2(4.54)$ & \\
\hline 3 or more & $8(18.18)$ & $10(22.70)$ & \\
\hline
\end{tabular}

AVRT: Atrioventricular reciprocating tachycardia; AVNRT: Atrioventricular nodal reentrant tachycardia; AT: atrial tachycardia; WPW: Wolf Parkinson White; VT: ventricular tachycardia; RFA: radiofrequency ablation; EPS: electrophysiological study. 
logical study, the rhythm disorders detected in respective number of patients were as follows: atrioventricular reentrant tachycardia (n:20; 44.4\%), atrioventricular nodal reentrant tachycardia ( $\mathrm{n}: 14$; $31 \%)$, ventricular tachycardia ( $n: 5 ; 11.2 \%)$, sinus tachycardia ( $\mathrm{n}: 4 ; 8.8 \%)$, and atrial flutter ( $\mathrm{n}: 2 ; 4.4 \%)$. The SCARED scale scores for both groups are presented in Table 2.

Table 2. Comparison of the SCARED scores in EPS and control groups.

\begin{tabular}{lccc}
\hline & $\begin{array}{c}\text { EPS group } \\
\text { (mean } \pm \text { SDS) }\end{array}$ & $\begin{array}{c}\text { Control group } \\
\text { (mean } \pm \text { SDS) }\end{array}$ & p value \\
SCARED P & $20.72 \pm 13.38$ & $4.41 \pm 2.29$ & $<0.001$ \\
SCARED C & $21.09 \pm 13.25$ & $4.97 \pm 2.77$ & $<0.001$
\end{tabular}

EPS: electrophysiological study; SCARED C: Child Screen for Anxiety Related Emotional Disorders Child version; SCARED P: Screen for Child Anxiety Related Emotional Disorders Parent version.

There was no difference between the groups with regard to parent-child closeness, marital status, and number of siblings ( $p=0.23, p=1, p=0.37)$. Parents' educational status and their sociodemographic data are presented in Table 3. No difference was determined between the case and the control groups in terms of the number of children born, maternal age, family income status, parents' profession, and family history of medical and psychiatric disease(s) $(p=1$, $p=0.157, p=0.794, p=0.371, p=0.884)$. Families of the children included in the study were classified as nuclear family (79.5\%), wide family (6.81\%), and parents were divorced in $9.5 \%$ of the families without any difference between the patient and control groups with respect to these parametres.

Table 3. Parent's educational status, patient and control groups.

\begin{tabular}{|c|c|c|c|c|}
\hline \multirow[b]{2}{*}{ Parent education } & \multicolumn{2}{|c|}{ Mothers } & \multicolumn{2}{|c|}{ Fathers } \\
\hline & $\begin{array}{c}\text { EPS } \\
\text { group } \\
n(\%)\end{array}$ & $\begin{array}{l}\text { Control } \\
\text { group } \\
\text { n (\%) }\end{array}$ & $\begin{array}{c}\text { EPS } \\
\text { group } \\
\text { n (\%) }\end{array}$ & $\begin{array}{l}\text { Control } \\
\text { group } \\
\text { n (\%) }\end{array}$ \\
\hline Illiterate & $2(4.54)$ & $3(6.66)$ & $1(2.27)$ & $1(2.38)$ \\
\hline Primary school & $25(56.80)$ & $28(62.22)$ & $17(38.63)$ & $19(45.23)$ \\
\hline Secondary school & $3(6.81)$ & $1(2.22)$ & $8(18.18)$ & $8(19.00)$ \\
\hline High school & $8(18.18)$ & $7(15.55)$ & $11(25.00)$ & $8(19.00)$ \\
\hline College or university & $6(13.63)$ & $6(13.33)$ & 7 (15.90) & $6(14.20)$ \\
\hline Total & $44(100)$ & $45(100)$ & $44(100)$ & $42(100)$ \\
\hline
\end{tabular}

EPS: electrophysiological study.

\section{DISCUSSION}

In our study, we found a higher level of anxiety in children who were hospitalized for electrophysiological study than the control group. Hospitalization for children is often associated with facing the fear of medical examinations, pain, loss of control, all of which increase anxiety ${ }^{(14)}$. Hospitalization for catheterization causes stress on the child and family. Previous studies have focused on measuring anxiety levels in the families of children with heart disease rather than diseased children. Kobayashi et al. (15) reported that anxiety levels were significantly higher among parents before cardiac catheterization, although the trait anxiety level of the parents was otherwise normal. In addition, they found that families of infants, adolescents, and children who had no history of angiography experienced higher anxiety levels. In our study, most patients were adolescents; similarly, anxiety levels were at a higher level.

Goldberger et al. ${ }^{(16)}$ evaluated the factors effective on patient anxiety using a detailed informed consent protocol before electrophysiological study. Patients were divided into two groups as those receiving form $A$, which did not explain the specific risks, and $B$ that did explain the specific risks. They found that situational anxiety was higher in Group B, and these patients needed more often anxiolytic therapy during the procedure. Conversely a study showed that children undergoing cardiac catheterization coped with stress more easily when the procedure was explained with videos ${ }^{(17)}$.Music therapy, educational videos, nurse training, and therapeutic massages have been shown to be effective in reducing anxiety in adult patients ${ }^{(18)}$. The identifying non-pharmacological strategies to reduce anxiety in patients undergoing cardiac catheterization is very important to improve nursing care and to prevent the negative effects of anxiety on patients' clinical outcomes, such as tachycardia and chest pain ${ }^{(18)}$. Children feel safer and their anxiety is reduced when they maintain a daily routine, which facilitates coping with the 
procedure of electrophysiological study.

Distress and hopelessness are usually at a higher level in parents who have children with congenital heart disease ${ }^{(19)}$. Üzgeret al. ${ }^{(20)}$ found, higher anxiety levels in children of families with cyanotic heart disease and anxiety levels were found to be compatible with the severity of the disease. More than $30 \%$ of adult patients with congenital heart disease, suffer from post-traumatic stress disorder and $25 \%-50 \%$ of them experience a major depressive disorder ${ }^{(21)}$. It was also found that emotional functioning is frequently adversely affected in these patients. Uzarket al. ${ }^{(22)}$ detected lower emotional functioning scores in children with heart disease compared with healthy children. Successful treatment of cardiac arrhythmias by ablation results in a significant improvement in the quality of self-reported emotional functioning scores in young patients ${ }^{(23)}$. Therefore, it is clearly important to undertake a psychosocial evaluation in addition to any physical evaluation.

\section{CONCLUSION}

In our study the anxiety of children hospitalized for electrophysiological study was found to be significantly higher than those in the control group. Electrophysiological study significantly increases anxiety in children, which affects the amount of anesthesia required for the procedure. The use of anesthesia at high doses makes it difficult to trigger arrhythmia. Therefore, trying to reduce anxiety and stress before the procedure can contribute to the success of the operation. We conclude that it is important to evaluate the psychosocial status of children who have chronic arrhythmia problems, especially before completing an electrophysiological study.

Ethics Committee Approval: SBU. İzmir Tepecik Health Practice Research Center Non-Interventional Ethics Committee approval was obtained (2019/12-3).
Conflict of Interest: None.

Funding: None.

Informed Consent:Informed consent was obtained.

Etik Kurul Onayı: SBÜ. İzmir Tepecik Sağlık Uygulama Araştırma Merkezi Girişimsel olmayan Etik Kurul onayı alınmıştır (2019/14-18).

Çıkar Çatışması: Yazarlar çıkar çatışması olmadığını beyan ederler.

Finansal Destek: Yazarlar herhangi bir finansal destek olmadıklarını beyan ederler.

Hasta Onamı: Hasta onamları alınmıştır.

\section{REFERENCES}

1. Bobbo M, Amoroso S, Tamaro G, et al. Retrospective study showed that palpitations with tachycardia on admission to a paediatric emergency department were related to cardiac arrhythmias. Acta Paediatr Oslo Nor. 2018;108(2):328-32. [CrossRef]

2. Hafez $M$, Abu-Elkheir $M$, Shokier $M$, et al. Radiofrequency catheterablation in children with supraventricular tachycardias: intermediate term followup results. Clin Med Insights Cardiol. 2012;6:7-16. [CrossRef]

3. Gillette PC, GarsonA. Pediatric Arrhythmias: Electrophysiology and Pacing. Philadelphia, PA: WB Saunders Co; 1990.

4. Blaufox AD. Catheter ablation of tachyarrhythmias in small children. Indian Pacing and Electrophysiology Journal. 2005;5(1):51-62.

5. Perry JC, Garson A Jr. Supraventricular tachycardia due to Wolff-Parkinson-White syndrome in children: Early disappearance and late recurrence. J Am Coll Cardiol. 1999;16:1221-3.

6. Calkins H, Sousa J, Rosenheck $\mathrm{S}$ et al.Diagnosisandcure of the Wolff-Parkinson-White syndrome or paroxysmal supraventricular tachycardias during a single electrophysiologic test. N Engl J Med. 1991;324:1612-1618. [CrossRef]

7. Gupta M,ShivapourJ, Lawrence A et al. Does Anesthesia Induction during Electrophysiologic Studies Induce Tachycardia in Pediatric Patients. Cardiovasc Dis Diagn. 2016,4:4. [CrossRef]

8. Caldwell R M, Ray R. Utilization of iPad technology to decrease pediatric preoperative anxiety. Journal of Pediatric Surgical Nursing. 2017;6(4):103-12. [CrossRef]

9. Cadman D, Boyle M, Szatmari P, Offord DR. Chronic illness, disability, and mental and social well-being: Findings of Ontorio Child Health Study. Pediatrics. 1987;9:805-3.

10. Dougall MJ, DeWit DJ, Wright FV. Social anxiety symptoms among youth with chronic health conditions: trajectories and related factors. Disability and Rehabilitation. 2020;42(23):3293-3305. [CrossRef]

11. Celano CM, Daunis DJ, Lokko HN, Campbell KA, Huffman JC. Anxiety disorders and cardiovascular disease. CurrPsychiatr Rep. 2016;18(11):838-44. [CrossRef]

12. Birmaher B, Khetarpal S, Brent D, et al. The screen for child anxiety related emotional disorders (SCARED): scale construction and psychometric characteristics. J Am Acad Child 
Adolesc Psychiatry. 1997;36(4):545-53. [CrossRef]

13. Çakmakçı FK. Çocuklarda Anksiyete Bozukluklarını Tarama Ölçeği Geçerlik ve Güvenirlik Çalışması, Çocuk ve Gençlik Ruh Sağlığı Dergisi. 2004;11:2.

14. Delvecchio E, Salcuni S, Lis A, Germani A,DiRiso D. Hospitalized Children: Anxiety, Coping Strategies, and Pretend Play. Front. Public Health. 2019;7:250. [CrossRef]

15. Kobayashi D, Turner DR, Forbes TJ, Aggarwal S. Parental anxiety among children undergoing cardiac catheterisation. Cardiology in the Young. 2018;28:315-21. [CrossRef]

16. Goldberger JJ, Kruse J, Parker MA, Kadish AH. Effect of informed consent on anxiety in patients undergoing diagnostic electrophysiology studies. American Heart Journal, 1997;134(1):119-26. [CrossRef]

17. Uzark K, Klos D, Davis W, Rosenthal A. Use of videotape in the preparation of children for cardiac catheterization. Pediatr Cardiol. 1982;3:287-91. [CrossRef]

18. Ferreira C, Ramalho Eda S, LopesJde L. Non-pharmacological strategies to decrease anxiety in cardiac catheterization: integrative review. Rev Bras Enferm. 2015;68:1093-1102.

\section{[CrossRef]}

19. Lawoko S, Soares JJ. Distress and hopelessness among parents of children with congenitalheartdisease, parents of children with other diseases, and parents of healthy children. J Psychosom Res. 2002;52:193-208. [CrossRef]

20. Üzger A, Başpınar O, Bülbül F, Yavuz S, Kılınç M. Evaluation of depression and anxiety in parents of children undergoing cardiac catheterization. TurkKardiyol Dern Ars. 2015;43:53641. [CrossRef]

21. Deng LX, Khan AM, Drajpuch D, et al. Prevalence and correlates of post-traumatic stress disorder in adults with congenital heart disease. Am J Cardiol. 2016;117(5):853-7. [CrossRef]

22. Uzark K, Jones K, Slusher J, Limbers CA, et al. Quality of life in children with heart disease as perceived by children and parents. Pediatrics. 2008;121:1060-7. [CrossRef]

23. Corcia MCG, Peters L,SluysmansT, et al. Quality of life assessment in children before and after a successful ablation for supraventricular tachycardia. Cardiology in the Young. 2020;30(3):413-7. [CrossRef] 